\title{
FINANCING THE NATIONALIZED INDUSTRIES
}

\author{
G. F. WHELDON*
}

I

Government spokesmen have frequently emphasized that their approach to the problems of nationalization has been based on the merits of each case. These indications of policy have usually been intended to apply to such broad questions as which industries should be nationalized or how they should be taken over, but a similar variety of approach is discernible in the more restricted field of the methods adopted for financing the industries once they have been taken over. To some extent these differences are attributable to the differing physical nature of each industry but the methods of acquisition and compensation, the choice of organizational forms and the price and profit policy followed, to which more extensive reference is made in other articles in this symposium, have also played their part.

In regard to the provision of finance, three nationalized undertakings have peculiar features. The Bank of England stands in a class apart, since the Act which nationalized the Bank made no provision for financing its subsequent operations nor for the publication of any report from which the methods adopted might be judged. The Bank has, as an act of grace, published an annual report each year since nationalization, but the information therein is somewhat meagre, and the value of the extensive real estate holdings, including the rebuilding and extensions now in progress, is not distinguished in the balance sheet. The absence of any reference to finance in the nationalizing Act or the new Charter is perhaps explainable by the facility with which a bank can create money by credit expansion. Indeed, the Bank of England, being the central bank of the country and not now in any way restricted by the size of its gold or other reserves, is able to create money at will. This ability, of course, is exercised only in close agreement with the broad lines of governmental financial policy as a whole, and in any event, the amount of new finance required annually by the Bank for its own purposes must be comparatively small and would certainly be dwarfed by the vast sums needed in other nationalized industries.

Another peculiarity concerns the airways corporations, for it was envisaged that, unlike other nationalized concerns, these might have to be operated at a loss, at any rate in the early years, and provision was made for subsidies from public funds. For each financial year the corporations are required to submit to the Minister of Civil Aviation estimates of their expected revenue and expenditure, and on the basis of these estimates and other information, the minister determines the amount, if any, of the grants which may be made to them from the Exchequer at the end of

* B. Com. (London). Assistant Manager, Intelligence Department, Midland Bank Limited, London. 
the year. In practice, the minister has rarely completed his determination of these subsidies before the start of any financial year, but payments on account are permissible, even though the total is not settled, and these reduce the need to resort to temporary borrowing to cover operating deficits until the full Exchequer grants are received.

Thirdly, the National Coal Board had financial problems which other boards were spared in that, unlike them, it did not take over existing administrative facilities with banking accounts, cash balances, securities, and reserve funds, but had to start from scratch, receiving its initial working funds as an advance from the Exchequer and building up its own financial organization. In the other industries, the whole of the assets and liabilities were taken over on the appointed days and the new bodies were therefore able to have immediate access to substantial financial resources or facilities provided by the former owners. The British Transport Commission, for example, took over bank balances and marketable securities amounting to over $\oint_{2} 200$ millions. These large liquid reserves had arisen mainly as a result of the abnormal conditions during the war when expenditure on railway maintenance was drastically curtailed even though financial provision continued to be made. The figures for other industries, though less spectacular than for transport, were also substantial. The British Electricity Authority took over from absorbed undertakings salable securities valued at over $£ 44$ millions and net cash and bank balances of $f_{4} 1 / 2$ millions, though it also inherited net bank overdrafts of $f_{17}$ millions in respect of the absorbed local authority undertakings. The initial figures for the gas industry have not been published, but it is known that several of the absorbed undertakings had substantial liquid resources immediately prior to the vesting date and the area gas boards still had over $£ 8$ millions worth of securities at the end of their first accounting period. For the Transport Commission these initial resources have thus far been sufficient to meet all capital and maintenance expenditures and large payments for the voluntary acquisition of road transport undertakings as well as the current losses on railway operations. For the other bodies additional finance has had to be provided since vesting day and, as all nationalized undertakings-including the Transport Commission-are likely to require large amounts of new capital over the next decade or so, the methods of providing this finance are of considerable importance, particularly in an economy where capital resources are already strained. It may be estimated that the nationalized undertakings are at present responsible for over $£ 300$ millions of the gross capital formation of about $£ 2,300$ millions a year.

In the various nationalization measures, Parliament has specifically eschewed detailed control over the day-to-day running of the various industries, but ministerial control is effectively exercised over the broad lines of capital development and finance. Proposals for new development, and also some of those for the renewal or maintenance of existing physical works, are submitted annually by each industry in broad aggregates to the Investment Programmes Committee, the coordi- 
nating authority set up by the Government to exercise oversight over capital expenditure in general. Within the broad limits laid down and revised from time to time by this Committee, the appropriate minister determines the general lines of the development program for each industry. The legislative limitations on borrowing powers, whether short- or long-term, have in all instances provided that the powers shall be exercised only with the consent of the minister and with the approval of the Treasury. For short-term borrowing the usual procedure has been to give a general authorization with an overall limit on the amount at any time outstanding, but for long-term borrowing the consents and approvals are given specifically on each occasion. The Treasury was required by the original nationalization acts to guarantee the principal and interest in respect of all stocks issued for the compulsory acquisition of assets then taken over, but for subsequent short- and long-term borrowing such guarantees were permissive and not mandatory. In practice, however, Treasury guarantees have been given for almost all borrowing except internal or inter-group finance. The guarantees for short-term borrowing from the banks are generally cancelled when repayment of the overdrafts is made out of the proceeds of long-term issues.

\section{II}

For working capital and other short-term requirements the financial arrangements have been comparatively simple, since the large banks with their nation-wide network of branches are well able to meet the needs even of such large borrowers as the British Electricity Authority, especially as all borrowings from the banks are supported by a specific Treasury guarantee. In two of the earlier nationalization measures limits were placed on the amounts of short-term borrowing (coal $f_{\mathrm{ro}^{1}}$ millions; transport $25_{2}$ millions); in the others no specific limits were placed on short-term finance, but an overall limit was set for all forms of new borrowing (British Overseas Airways Corporation $f^{60}$ millions, British European Airways Corporation $f_{2} 20$ millions, British Electricity Authority and the area boards $£ 700$ millions, North of Scotland Hydro-Electric Board £100 millions, Gas Council and its area boards $£ 250$ millions, the Iron and Steel Corporation of Great Britain and its companies $£ .35^{\circ}$ millions). In general, nationalization has resulted in a considerable reduction in the number of separate banking accounts required, though the aggregate turnover has probably continued to expand. Technical arrangements were made, by voluntary agreement between the banks and the central authorities of each nationalized industry, for the banking business, including credit accounts as well as overdrafts, to be spread over all the leading banks roughly in the same proportions as they had shared the banking business of the absorbed undertakings, though exceptional, short-term bank borrowing by the airways corporations has been concentrated on one bank. In general, the tendency has been to concentrate the borrowing or principal credit balances into a

\footnotetext{
${ }^{1}$ This limit was raised to $£ 20$ millions by the Coal Industry Act I951, 14 \& 15 Geo. 6, c. 41 .
} 
few central accounts, usually held in London, and to operate small credit accounts for local purposes in other parts of the country.

Resort to the banks for short-term finance, though usual, is not obligatory. The National Coal Board, for example, has obtained its working capital in the form of advances from the Minister of Fuel and Power, the bank "overdrafts" recorded in its balance sheet as at December 3r, I949 being nominal in the sense that they represented the effect which would have been produced had all outstanding cheques been presented for payment rather than actual accommodation granted by the banks. In I947 and 1948 British Overseas Airways Corporation used temporarily surplus funds to make large loans at short call to the two other airways corporations (subsequently, one of these was amalgamated with B.O.A.C.). The Transport Commission in 1949 exercised part of its temporary borrowing powers in order to obtain $£^{1} 1 / 2$ millions at short call from the London Electric Transport Finance Company, which is a special corporation formed in 1935 under official auspices to lend money primarily for railway electrification in the London area. The Gas Council borrows from area gas boards which have temporarily surplus cash balances and re-lends to other area boards which are in need.

III

When we turn to the provision of long-term capital, a somewhat greater variety of method is observable. For the coal industry the only source permitted by statute is the Ministry of Fuel and Power. The limit set by the original Act was ${ }^{2} \oint_{150}$ millions for the first five years, i.e., up to July I2, I95I, and the net amount so borrowed by April, I951, including sums for working capital and allowing for repayments, was just under $£ 33$ millions. This figure, incidentally, is much lower than that recorded as issues under the Act in the "below-the-line" section of the Exchequer return (the weekly record of Government receipts and payments), since the greater part of these cash issues has been in respect of compensation to former colliery owners for particular assets transferred to the Coal Board at the beginning of 1947. Long-term borrowing by the airways corporations has been by way of issuing blocks of Airways Stock to the National Debt Commissioners. The British Transport Commission has had no occasion to make use of its borrowing limit of $\$ 25^{\circ}$ millions for ordinary capital development, since, as indicated above, it inherited a wealth of cash and marketable securities from the undertakings it absorbed in I948; but $£ 25$ millions of British Transport 3 per cent Guaranteed Stock 1968-73 was issued to Thomas Tilling Ltd. in 1948 as consideration for the voluntary transfer of Tilling's interests in road haulage and passenger undertakings, and by the end of $195^{\circ}$ other negotiated acquisitions of road passenger undertakings had resulted in the issue of nearly $\$ 25$ millions more of this stock.

In the electricity industry, the principal method adopted to provide long-term

a This limit has been raised to $£_{300}$ millions without any expiring date by the Coal Industry Act, 1951. See note I stipra. 
finance has been initially to borrow the sums required from the banks and, when the total became large, to make a funding issue to the general public. The borrowing is in the name of the British Electricity Authority though the funds are used not only for its own purposes, mainly generation and bulk transmission, but also, by process of re-lending, for the purposes of the area boards which are concerned mainly with detailed distribution to consumers. Temporary borrowing, from the banks and other sources, rose to nearly $£_{50}$ millions by October $194^{8}$ when a public issue of fIoo millions of British Electricity 3 per cent Stock 1974-7 was made at $991 / 2$. The proceeds were used to repay the temporary borrowing and to finance the still growing expenditure on new capital development. This growth of expenditure was such that by May 1950 the Authority was once more "in the red" at the banks to the extent of about $\AA_{65}$ millions. The amount of British Electricity Stock then issued to the public was $f_{150}$ millions, but the terms were somewhat less favorable to the borrower, the interest rate being $3^{1 / 2}$ per cent, the issue price 99, and the redemption dates $1976-9$. The North of Scotland Hydro-Electric Board has adopted a broadly similar method of financing capital development. Initially, funds are obtained at short-term, mainly from the Scottish banks, and at intervals refunding is undertaken. It is generally believed that the first public issue, in July 1947, of $£_{5}$ millions of $21 / 2$ per cent Guaranteed Stock $1967-72$ at par, was fully taken up only as a result of heavy subscriptions by the Scottish banks themselves, and it is perhaps significant that the four subsequent issues, together amounting to $f_{37}$ millions of 3 and $3^{1 / 2}$ per cent Guaranteed Stocks at par or just over, were all made to the National Debt Commissioners.

In the gas industry the "normal" method of providing long-term finance appears to be similar to that adopted for electricity, but one point of difference may be noted. The degree of decentralization in the control and management of the gas industry is greater than for electricity, and temporary borrowing to finance capital construction may be undertaken by the Area Gas Boards, as well as by the Gas Council, but only the Council may issue British Gas Stock. The first issue of British Gas Stock, apart from the compensation stocks to the former owners, was made in May 1949 to the National Debt Commissioners, in the form of $\oint_{40}$ millions of 3 per cent stock at 1001/2 redeemable r $990-5$. The second issue, in July 195I, was of $£ 75$ millions of $3^{1 / 2}$ per cent stock at 98 redeemable $1969-71$, and was made to the general public. At the time of the issue the Gas Council had banks' overdrafts amounting to just over $£_{4} 4 \frac{1}{2}$ millions.

The time that has elapsed since the take-over of the iron and steel industry has been too short to determine the "normal" method of providing finance, but special features are likely to arise as a result of the decisions to maintain the existing company structure of the industry rather than to transfer the ownership of the physical assets to specially created boards, and to give certain creditors of the companiesparticularly the Finance Corporation for Industry-the right to demand early re- 
payment of their loans. So far the Iron and Steel Corporation has made no longterm issue, but a Treasury guarantee has been given in respect of short-term borrowing up to $f_{20}$ millions from the banks.

The National Debt Commissioners, already referred to on several occasions as subscribers to large amounts of the stocks of nationalized undertakings, are a long established public body, charged with the investment of the surplus resources of the post office and trustee savings banks, the national insurance funds, and other public institutions. In general the terms of issue to them have corresponded closely with the stock exchange quotations for comparable direct government obligations. The various stocks taken up by the Commissioners from time to time are not necessarily held by them in perpetuity; indeed, there is evidence to suggest that for some stocks they act rather in the manner of underwriters or investment bankers, taking up the whole of an issue and then retailing it out to the big institutional and other permanent buyers as opportunity offers.

\section{IV}

So far we have described the main methods of finance undertaken within the specific bòrrowing powers laid down by legislation, but, in addition, the nationalized undertakings are pursuing a considerable measure of self-finance out of their own reserves and other internal funds. The first report of the British Electricity Authority, for example, stated that

moneys set aside by the Authority and Boards as annual provision for depreciation of assets, or discharge of their capital expenditure, and other corporate savings such as revenue surpluses and reserves, provide supplementary sources from which capital expenditure may be met.

In so far as conservative estimates of the life of plant are adopted and liberal provision is made for depreciation, it is likely that considerable sums will be available each year for new capital investment over and above the replacement of worn out or obsolete assets, especially as the electricity industry is still in a phase of rapid expansion. Total provisions for depreciation and writing off intangible assets exceeded $f_{64}$ millions in the two years to March, I950; three-fifths of this was used to repay various capital liabilities and the remaining $£_{2} 6$ millions was available for. financing new construction. In addition, both the Central Authority and the Area Boards are required to establish and maintain reserve funds, and in the first two years the net sums thus set aside amounted to about $£ 8$ millions, while the amount carried forward was about $£ 21 / 2$ millions. The Transport Commission, too, has set aside large annual sums for depreciation- $f_{2} 2$ millions in $1948, f_{24} 3 / 4$ millions in I 949 and $f_{2} 283 / 4$ millions in 1950 -but as its main sphere of activity, the railway system, is no longer rapidly expanding, most of the provisions have had to be used to replace the large volume of existing worn out assets, rather than to finance further expansion. For the coal industry, the Ministry of Fuel and Power has said that the 
National Coal Board is expecting to finance out of its depreciation provisions as much as three-quarters of its projected gross capital expenditure of $f^{6} 635$ millions over the next fifteen years.

The extent to which self-finance can be practiced should not, however, be exaggerated, since all the nationalized industries are subject to the same taxation as similar private enterprises, and are therefore likely to experience similar difficulties in setting aside substantial sums out of current earnings for expansion. The Commissioners of Inland Revenue may be expected to disallow excessive provision for depreciation, while the high level of income and profits taxes will make the accumulation of substantial reserves a somewhat expensive procedure and likely to invite criticism from those who would prefer an immediate lowering of charges to the consumer. Even the "initial depreciation allowances," which so greatly benefit rapidly expanding industries, such as the Electricity Authority, in the earlier years, are merely tantamount to interest-free Treasury advances over the life of the respective assets, and the Chancellor of the Exchequer has given notice that they are to be suspended from April, I952, to lessen competition with the rearmament program.

Regulations made under the various nationalization measures provide, in effect, for the gradual redemption of the stocks issued fhe acquisition of assets or the raising of new money. This redemption of the stocks was intended to be distinct from and additional to the provisions made for the physical depreciation of assets, but for electricity and the airways corporations ministerial acquiescence has been obtained to treat the depreciation charges as sufficient amortization provision. In general, the period fixed for amortization is 90 years from the date of issue of the stock and the rate of interest to be assumed for redemption fund purposes is 3 per cent. ${ }^{3}$ The redemption funds are invested in marketable securities, usually British Government securities, and are not available for directly financing capital development of the undertakings, though by increasing the demand for government and government-guaranteed stocks in general they improve the prospects of placing the undertakings' own stocks.

A somewhat different method of amortization has been laid down for the coal industry. In accordance with the provisions of the original Act, the net expenditure of the National Coal Board has been met from funds provided by the Ministry of Fuel and Power. The practice has been for the Board to draw on the Ministry for sums required throughout the year, interest being charged at $1 / 2$ per cent on the ground that it is short-term finance, and immediately after the end of the year to fund these temporary advances into a single amount to be repaid by a terminable annuity of fifty equal annual instalments, the interest rate used for the calculations being the then current rate for long-term borrowing. Similar funding and repay-

\footnotetext{
"The "life" of most of the stocks is much less than 90 years, and they will thercfore have to be renewed or replaced by other issues at least once before final extinction under the amortization pro. visions.
} 
ment provisions apply to the compensation stocks issued or to be issued to former colliery owners, the Board being required to make fifty annual payments to the Ministry from the year of issue of each stock. The rate of interest used for the annuity calculations was $2 \frac{1}{2}$ per cent in respect of advances received and stocks issued before December 31, 1947, 3 per cent for those in 1948 and 1949, and $3 \frac{1}{2}$ for 1950. The capital portion of the annuities is used by the Treasury for repayment of government debt, and therefore like the redemption funds of the Transport Commission, may be regarded as lending support to the gilt-edged market.

Among other sources of internal finance available to the nationalized industries perhaps the most important, judged by amount, are the deposits by staff savings banks and staff superannuation funds which the British Transport Commission inherited from the railways. The savings bank deposits, amounting at the end of 1950 to $£ 43$ millions, are in the form of borrowings from the staff at shortterm, though in fact the total outstanding is not likely to fluctuate substantially from year to year. The superannuation deposits also, amounting to $£ 75$ millions at December 3I, I950, are morally, if not legally, funds belonging to employees. They do not include the whole of the superannuation funds, since some of these are invested by the trustees in other securities, but, so long as the practice is con-. tinued of investing a large proportion of the accruing funds within the organization, the Transport Commission can apparently count upon a growth of between $f_{1}$ and $£_{2}$ millions each year in the total which is available for long-term finance. In other nationalized industries the amount of superannuation funds invested within the business is comparatively small, and in all newly created schemes the practice has been to invest annual surpluses in other securities. Prepayments or deposits by consumers, as an earnest of good faith in settlement of accounts, are another form of finance available to some of the industries, notably electricity and gas, but, again, the amounts involved are relatively small and no substantial annual increase can be counted upon; indeed, some of the area boards are discontinuing the practice of requiring such prepayments and deposits. Another source of finance available to some of the nationalized industries has been the sale of assets taken over from the absorbed undertakings and not required for the purposes of the new body; the National Coal Board, for example, realized about $£_{12}$ millions from the sale of railway wagons and the Transport Commission over $f_{0}$ roo millions from the sale of securities in 1949 and $195^{\circ}$. These sales of inherited assets are naturally a non-recurring source of finance.

\section{$\mathrm{V}$}

In addition to securing additional finance for new investment, some of the nationalized industries have been faced with special problems arising from the methods of compulsory acquisition of the absorbed undertakings. For the Bank of England, special Treasury stock was created to give an annual income yield 
equal to that which former stockholders had received in each of the preceding twenty years; for the collieries the compensation stock is being issued on the basis of the capitalized value of the net maintainable income of the industry as a whole; for the railways, electricity, gas, and iron and steel, the capital amount of the compensation stocks was based on stock exchange values of the stocks and shares of the absorbed undertakings or on a negotiated figure where no stock exchange quotation was available. With the exception of the Bank of England, therefore, all the nationalized undertakings have been faced with accountancy problems in incorporating the capital liability on compensation stocks into balance sheets in which assets have been brought in at their former book values. In general, the problem is being solved by revaluation of the assets or by opening special adjustment accounts to represent the difference-whether surplus or deficit-at the time of acquisition. In so far as the stock exchange valuation of the former securities was a valid appraisal of their long-term real value the industries should not be faced with difficulty in meeting the annual interest commitment, especially as the rates payable on the compensation stocks are comparatively low; but if the revenue actually earned should fall appreciably short of the interest commitment, a question of public policy would arise as to the method of meeting the persistent deficit. The problem seems most likely to arise in the Transport Commission where the railway section is experiencing difficulty in paying its way. If the Commission is to be financially self-supporting, as is required by the Transport Act, 1947, the deficit might have to be met by increasing charges in other sections. The road haulage or road passenger section, for example, might be required in effect to subsidize the unprofitable railway section. Such a procedure, however, would be likely to arouse strong criticism from those consumers who would be called upon to pay more, and, already the Federation of British Industries has submitted a memorandum to the Minister of Transport proposing that part of the cost of maintaining Britain's railways should be charged to defence votes, on the grounds that many uneconomic lines and services have to be maintained for possible use in time of war.

\section{VI}

To summarize the methods adopted in practice to finance Britain's nationalized industries, it may be said that the industries are first expected to use their own resources of inherited funds or reserves set aside out of current receipts. If these are insufficient to meet approved expenditure, the government-by direct advances, by Treasury guarantees of borrowing from the public or the banks, or by arrangements with the National Debt Commissioners-gives them access to other funds on terms as favorable as those available to the government itself. Practically the whole of their finance, including the compensation stocks issued originally in respect of absorbed undertakings, is in the form of debt bearing fixed rates of interest, whereas in the absorbed undertakings much of the finance required had been pro- 
vided as equity capital receiving a variable return. The method of debt finance contributes in part towards the solution of the problems raised by the changing nature of the ownership of savings in Great Britain. In the nineteenth century capital was provided by a comparatively small number of wealthy men who were prepared to incur considerable risks in the hope of large gains; whereas in the changed circumstances of the twentieth century much money for development has to be obtained from the smaller saver or the institutional investor, both of whom probably regard security of capital as of greater importance than high, though variable, returns. The methods of finance adopted do not mean, however, that the risks inherent in all business enterprise have been eliminated from the nationalized industries; they have, in effect, been transferred to the community as a whole, either in the form of Exchequer-financed subsidies or by incorporation. into the prices charged for the goods and services rendered. The private saver has become a pure rentier and the taxpayer or consumer a willing or unwilling holder of the equity. 


\section{FINANCE OF NATIONALIZED INDUSTRIES*}

(figures in brackets show net figure after redemptions, cancellations, etc.)

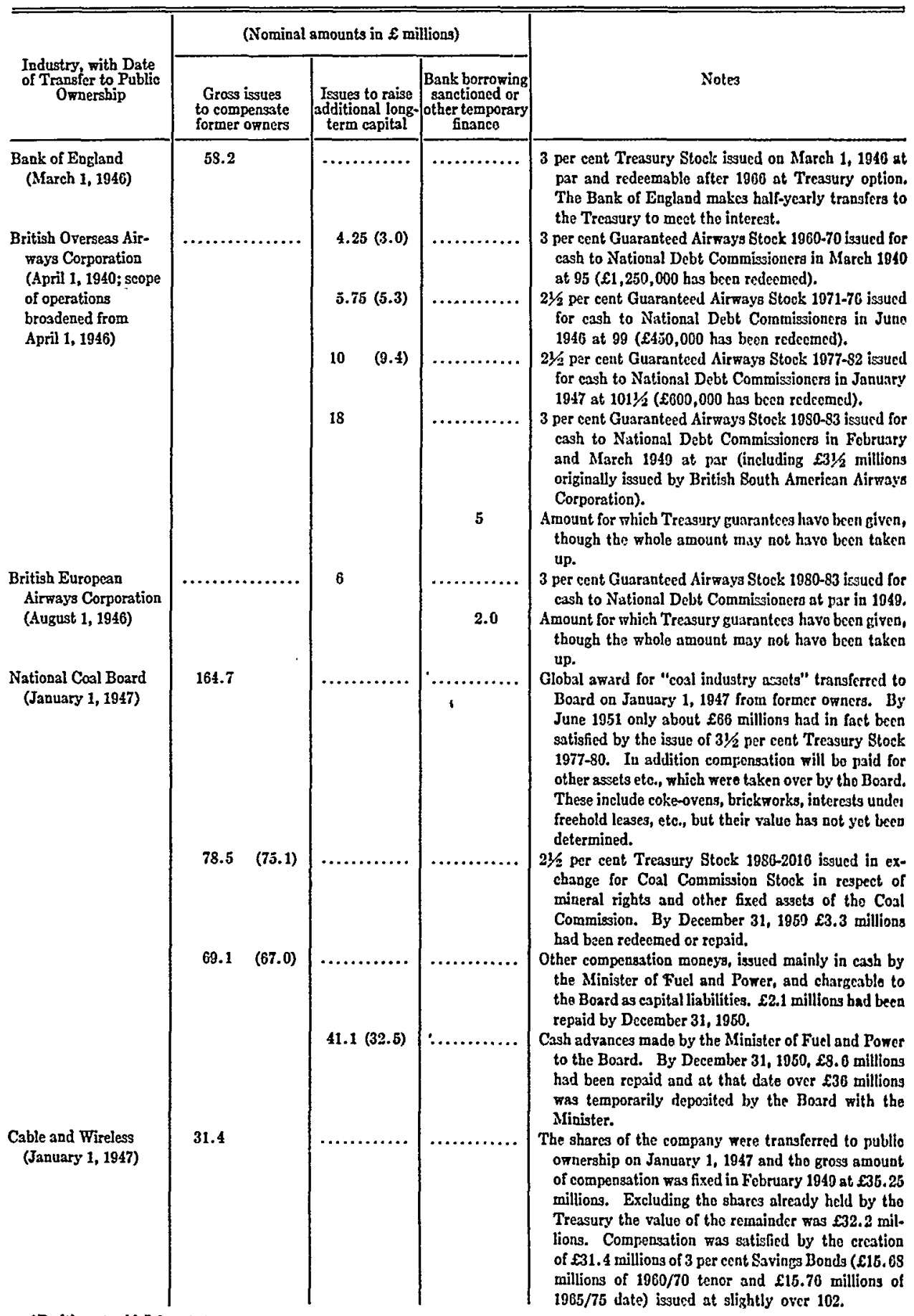

- Position at mid-July, 1951. 
FINANCE OF NATIONALIZED INDUSTRIES (Continued)

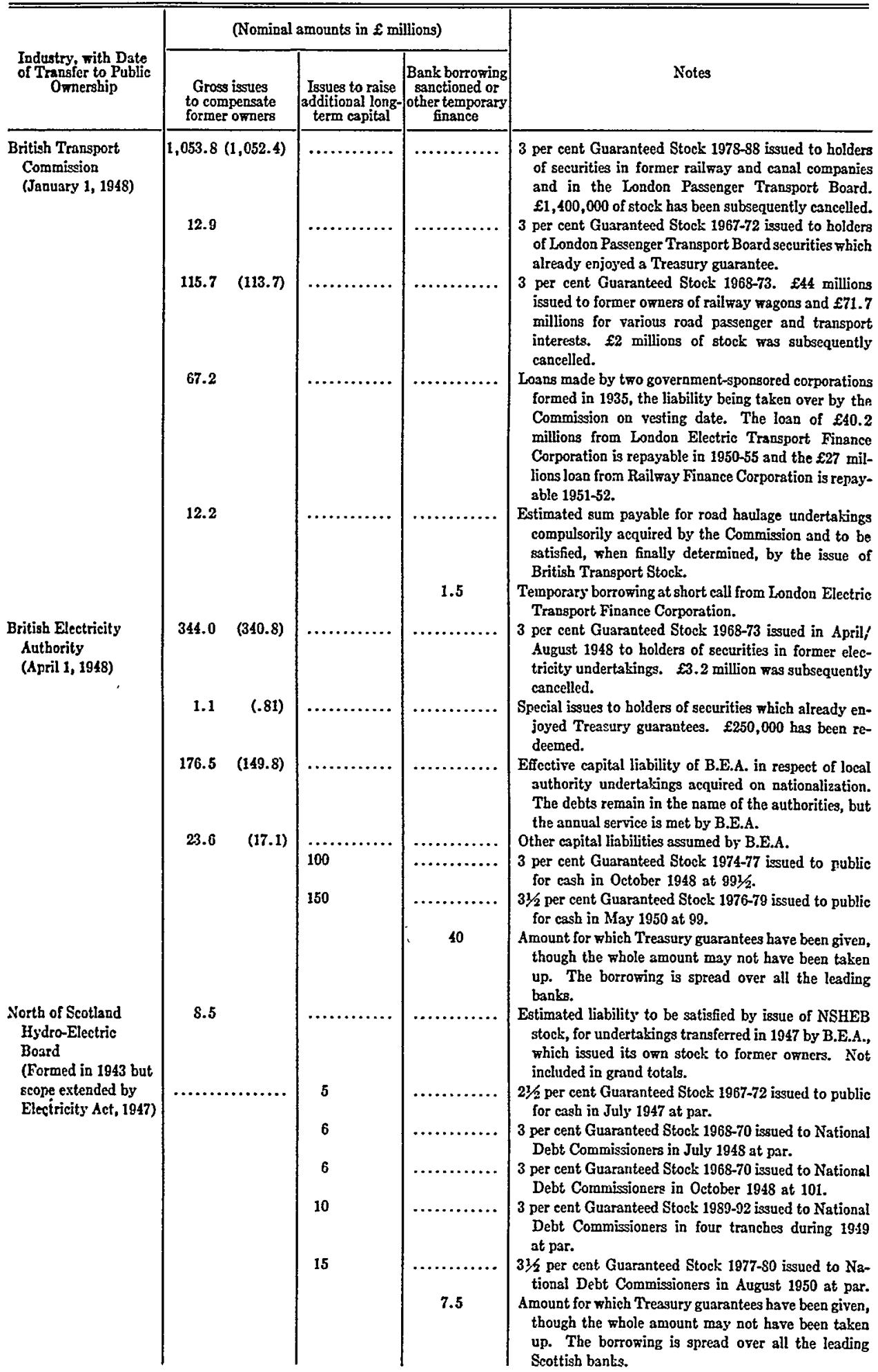


FINANCE OF NATIONALIZED INDUSTRIES (Continued)

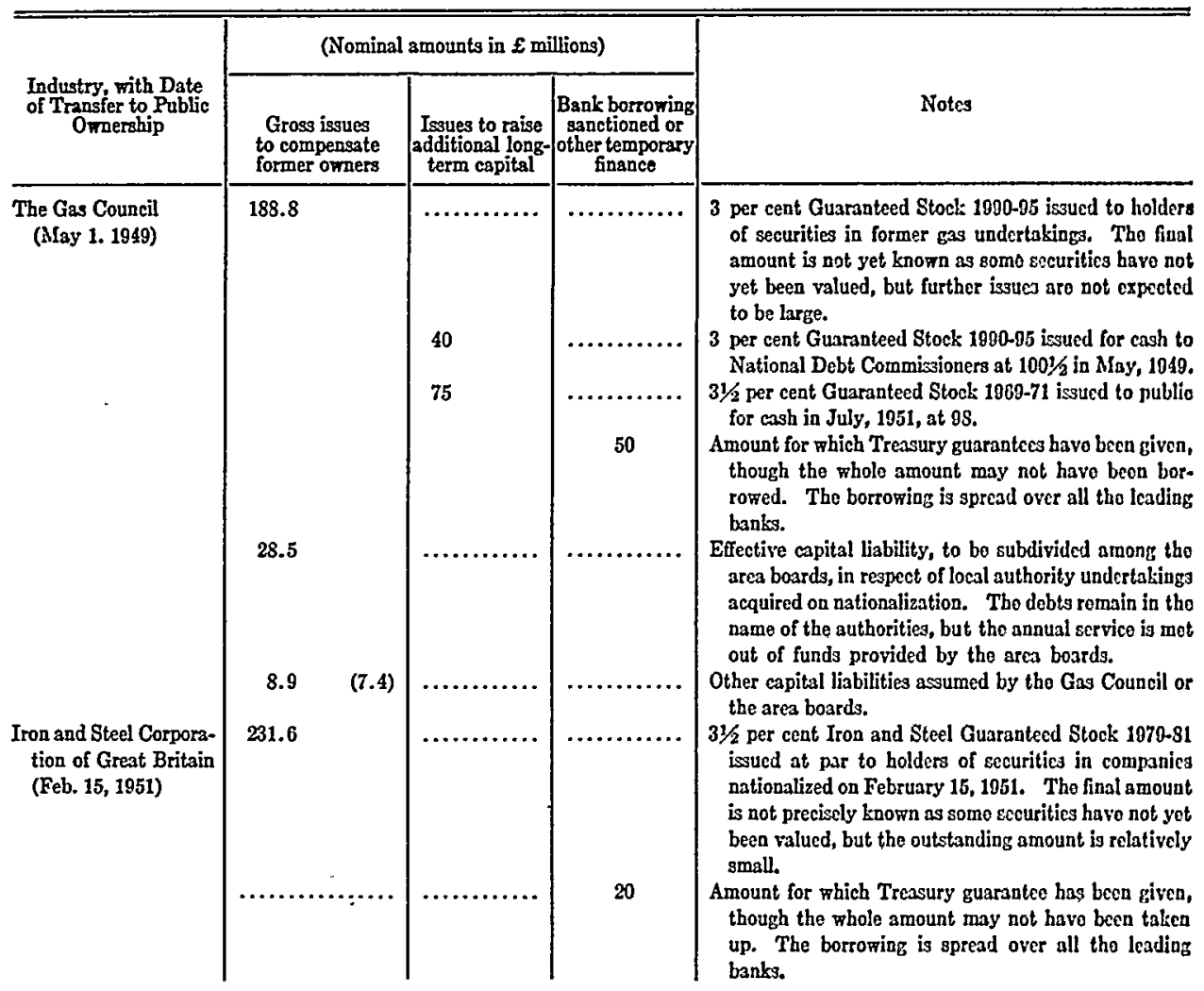

\section{SUMMARY OF PERMANENT FINANCE}

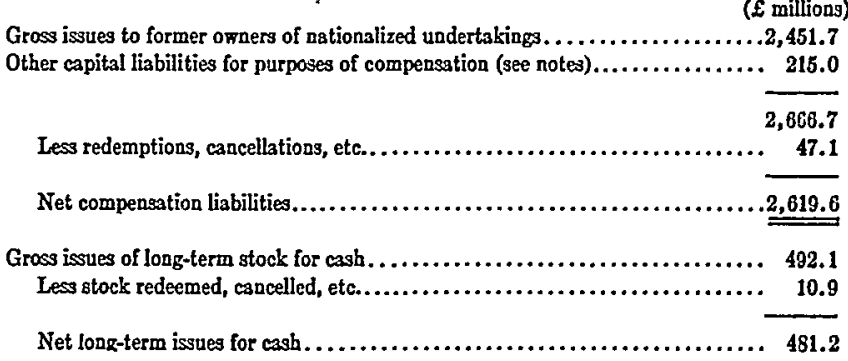

